\title{
Postmodern Attitude towards the Universe
}

\author{
Dr. Shanjendu Nath \\ M.A., M.Phil., Ph.D. Associate Professor and H.O.D., Department of Philosophy, Rabindrasadan Girls' \\ College, P.O. \& Dist. Karimganj, Assam, INDIA.
}

\begin{abstract}
There are extreme world views amongst the philosophers of different periods of history and the response of postmodernism in this regard is really a fatalist one. Postmodern world view is diametrically opposed to the modern worldviews. It attempts to view reality in a new way. It does not believe any kind of definite description and thus the modern intellectual outlook is radically rejected by it. Thus it can be said that both in our understanding of knowledge and science, postmodernism brought a revolution. In this paper I shall try to explain the postmodern attitude towards modern worldview and finally depict their own explanation of the universe.
\end{abstract}

Keywords: Enlightenment, Metanarratives, Modernism, Postmodernism, Worldview,.

\section{INTRODUCTION}

It is generally believed that postmodernism is a subsequent period of modernism and it developed its worldview by rejecting the worldview of modern thinkers. Now, before going to explain the attitudes of postmodernism towards universe it is necessary to have an idea about the term modernism and postmodernism.

Modernism is period of the last part of nineteenth century and first part of twentieth century. It describes a collection of cultural movement of that period. A series of reforming movements in art, literature, architecture, music and applied arts together constitute this period. In modernism we find dramatic change of thought, where people got chance to think freely. By involving science and technology, people admitted to improve every aspect of their lives. We see a trend of reform in that period including philosophy, commerce, art and literature and that was done with the help of technology experimentation. As a consequence there was a programme in all the aspects of human life. Postmodernism is not a thing or entity that is given so it defies all sorts of definitions. In fact, it is a movement which is found in almost each and every branch of study like philosophy, art, architecture, literature, poetry, drama, dance film etc. In narrating the status of postmodernism Bishop Gregorios writes,

"(Postmodernity) is a movement, it is an 'attitude' or a 'mood', but not a systematic thing where you can develop concepts and relationships, precisely what the postmodernists are against. Any attempt to over systematize thought by being reduced to any kind of system is to reduce thinking as such. So postmodernism is basically a mood."

Postmodernism is generally means a period after modernism. This period began after the second worldwar; particularly this period began its journey as a reaction early in 1968. This period began its journey as a reaction to the modernism. There were different disenchantment brought about by the Second World War and these have great influence in the mind of postmodern thinkers.

In distinguishing postmodern from that of modern Lyotard says,

"I will use the term 'modern' to designate any science that legitimates itself with reference to a metadiscourse of this kind making an explicit appeal to some grand narrative, such as the dialectics of Sprit, the hermeneutics of meaning, the emancipation of the rational or working subject, or the creation of wealth. For example, the rule of consensus between the sender and addressee of a statement with truth value is deemed acceptable if it is cast in terms of a possible unanimity between rational minds: this is the enlightenment narrative, in which the hero of knowledge works toward a good ethico-political end - universal peace............... Simplifying to the extreme, I define postmodernism as incredulity towards metanarratives." It is very difficult to define postmodernism because any attempt to define it is to violate the very premise of the postmodernists which states that there does not exist any definite terms, boundaries or absolute truth. Moreover, there is not found a single belief or opinion amongst the thinkers who claim themselves to be postmodernists.

${ }^{1}$. Gregorios, Paulos, Mar,"On Postmodernism”, (Translated by Dr. R.P.Singh) Journal of Indian Council of Philosophical Research, Vol.xiv, No. 3, May-Aug 1997, p-84

${ }^{2}$ Jean-Francois Lyotard: The Postmodern Condition: A Report on Knowledge, pp. XXIII-XXIV. 


\section{WORLDVIEW OF POSTMODERNISM}

The postmodernism occupies an important place on the intellectual map only when the publication of the book "The Postmodern Condition: A Report of Knowledge" was done. From the point of view of intellectual agenda, postmodernism attempts to view reality in a new way. Thus it can be said that postmodernism brought a revolution both in our understanding of knowledge and science. It does not believe any kind of definitive description and thus the modern intellectual outlook is radically rejected by it. In a sense it brought a revolution in knowledge. To say the truth, it declares the end of the universe. Thus as per its own declaration it is clear that there is no world view of the postmoderns. The object of our perception is the unified world but the postmoderns whole heartedly deny its reality. It holds that there is no possibility to construct a single and correct world view rather they hold that there are many views about the world and thereby there are many worlds. Thus it replaces the world view of modern age into multiple views and world. The postmodernists adopted interpretation in place of knowledge.

\section{POSTMODERNISM AS THE END OF THE WORLD:}

The objective world of the Enlightenment project is ended as soon as the modern world view loses its importance. The modern outlook assumes that there is an objective world around us. It also assumes that there is reality of human reason. This reality is not chaotic but in an orderly manner. As this order is manifested in the laws of nature, so human reason is able to discern and understand this order. Thus the presumption on which the Enlightenment project based is that these laws are to be discovered and utilized for the benefit of human being and thereby the purpose of human being will be fulfilled. The Enlightenment project and modernity stand on the foundation that we can have understanding of our knowledge of the world which the postmodernism totally rejects. More specifically it can be said that the notion of the reality of an objective world is negated by the postmodern era. The rejection of the objective world by the postmodernism is the outcome of their rejection of the knowledge and truth advocated by the realist philosophers. Thus, rejecting the realists' position, the postmodernism favoured non-realist understanding. This understanding of the postmodernism is actually a move from an objectivist to a constructionist outlook.

The fundamental assumption of the realist about the world is that it consists of physical objects where we are living and there are inherent properties in these physical objects by which we can easily identify them. But the postmodern thinkers reject this fundamental assumption of the realist and hold that the claim they have made is totally untenable. They look into the world from different perspective. According to them, the world is not simply out there in which we are living and encountering. Rather, the world is the construction of our mind. We construct this world by using our own concepts. They hold that apart from our own structuring of the world, there may be reality out there but we are not in a position to have purely objective view of it.

An assumption of the Enlightenment realist is that in between the list of language which we use to describe the world and that of the bits of itself which we seek to know, there exist a simple and one-to-one relationship. But this assumption of the Enlightenment realist is declared faulty by the twentieth century linguistic philosophers. The linguistic thinkers are of the opinion that the bits of language are not simply related with that of the bits of the world. Again, the accurate map of the world cannot be provided by any language. It is because of the fact that there are various ways through which the world can be mapped by languages, as languages are social conventions of human beings; but this depends on the context about which they are speaking.

The linguistic philosopher Wittgenstein is of the opinion that it is 'language game' for which all words are embedded. There is system of rules which defines each and every linguistic game. These rules govern the way in which the words are used within that context. It is for this reason Wittgenstein holds that there is resemblance between language and game. For example, the game Chess has certain rules which determine the condition under which the game pieces can be moved from one place to another. This view implies that the way we experience the world is coloured and altered by our various language games.

This view of linguistic philosopher helps the postmodern thinkers in rejecting the realist view and advocating a non-realist or constructivist view. Constructivists are of the opinion that in providing access to the world, the role of language is very important. They hold that the world which we call 'real' is actually a creation of our society and that is why it is ever-changing. The world is social reality and it is our common language through which we construct the world. We have chosen different categories for which we say that 'snow is white', 'grass is green' and 'the sky is blue'. Thus the meanings of the world are constantly changing because the social context is always changing.

There is another factor which also contributed for the diminishing of objectivist understanding. It was the assumption of the people of the west that the culture of the Enlightenment period is most advanced and civilized in the world. And so long this assumption lasted, the position of the Enlightenment retained its credibility. It was simple assumption of the moderns that Western ideal is very rich and the humankind as a whole would ultimately come forward to appreciate it and also strive to attain its benefits. But this dream of the 
moderns is no longer credible in the postmodern era. This has fallen victim to the phenomenon known as 'globalization'. Now-a-day, there are varieties of cultures by which people in the west are confronted with. Each culture has its own belief and its own picture of the world. Each people also honours and estimates high position of his own belief.

Thus the Enlightenment vision of the world has been overthrown by our globalised, pluralistic world view of the postmodern thinkers. Postmoderns are of the opinion that we cannot reasonably say that there is any possibility of discovering the one, universal symbolic world in future that will be able to unite humanity ignoring our differences. They rather hold that there are 'multiple realities' by which the world is consisted of and where we have been living. And as the different people encounter differently, so they construct different stories about the world and thereby they experience their lives in different ways. Thus apparently it appears that people hold a variety of political opinions and religious beliefs. But the actual picture is that, in respect of personal identity, time and space, (which are called basic matters of people), people live in different worlds.

There are two fundamental assumptions on which the postmodern understanding of knowledge is built. These are -

1. All explanations about reality are constructions of human mind. These explanations are not objectively true although useful.

2. We have no ability to go beyond our construction of reality.

It is to be noted here that the outlook of postmoderns is to attack realism and this attack is in the name of reason. According to them, apart from the structure of the world that we construct, there are no other possibilities to view it. Moreover, we are unable to compare our theories and propositions with that of an objective and external world and measure its value. It is rather worlds are created by the theories that we devise and we inhabit in it. Thus postmodern severely attacked realism and developed their own theory. They have rejected the notion of single objective world and adopted a pluralistic worldview and therefore adopted a pluralistic view of knowledge. They are not concerned with the question of correctness of propositions or theories. They are concerned with the outcome of it.

There are some postmodern scholars who claim that they are the harbingers of the realism. They think that they should manifest the fact that there are different concepts which are generally the result of cultural construction but which common people assume as common sense or universal. This task they take willingly in their own shoulders. They say that if the meaning is really constructed by language, then the task of the scholar is to deconstruct the meaning. They are hopeful that they will be able to break the realists control over thought and actions of common people and this is possible by deconstructing influential concepts of the realists.

Thus for the implementation of their outlook, the postmoderns demand a 'post-pedagogical classroom'. They opine that the purpose of teaching is not merely to transmit knowledge from one person to another. If it is supposed to be so, then the active production as well as deconstruction would be encompassed by it. Knowledge, according to them, lies before educational experience.

\section{POSTMODERNISM AS THE END OF "METANARRATIVE":}

The modern thinkers believe that there were myths and religious dogmas among the pre-modern people for which they were inevitably involved in wars and conflicts. But the goal of modern thinkers was to move beyond these entire phenomena and to build a new society, the foundation of which, they thought, will be universal rationality alone. The outlook of modern thinkers is very different from premodern outlook. In order to explain the world, the premodern thinkers were dependent on myths and stories but assumption of the modern outlook is the Enlightenment programme which is free from such dependency and their own discoveries is purely objective. Their claim is that they are fully competent to depict the world what it really is. But postmodernism outrightly deny the claim of the moderns and declare that this is nothing but illusion.

There are different changing factors which help to expedite the postmodern thinkers to reject the Enlightenment hubris. The anthropologists of the twentieth century became more and more aware of the myths that were prevalent in human society as its foundation. There were different stories found in primitive cultures but some scholars are of the opinion that myths are more important than that of the stories. Some of them further hold that these myths are, in fact, religious because the values and beliefs of a culture, which are central core of it, are incorporated in myths. They conclude from their research that system of myths bind together each and every society and social relation is sustained by these myths within the society and thereby on the basis of these, they claim the legitimacy of these myths.

These systems of legitimizing the myths are regarded by the postmodern thinkers as "narratives" or "metanarratives". According to them, in addition to argumentation and proof, a narrative exercises a force and the principal means by which every community legitimates itself is, in fact, provided by this narrative force.

It is the claim of the modern outlook that with the help of rational postulate they have replaced the myths. But such claim of modern outlook is rejected by the postmodern. According to the postmoderns, it is the 
Christian narrative interpreting which the scientific method was developed and modernity was born. The Christian narrative believes that a universe is created by a rational God. This God, according to it, is sovereign over this universe. Thus as the modernity was born out of an interpretation of Christian narrative so, according to postmodern, it is itself dependent on it. The modern era believes the myth that a better world for human being can be created by means of technological invention and economic development. By legitimating these means it claims itself as the embodiment of a narrative of progress. But the postmoderns are of the opinion that in no way moderns are 'free' from the directive force of myths. The famous postmodern thinker Lyotard observes that the modernity has lost its importance not because of its failure to sustain faith in rational postulate but because of its narrative. The grand narrative by which modern society was legitimated has lost its power for which modernity has been declining. He holds that this is scarcely a unique situation. It is evident from the history that there is a series of transition from one defining myth to another defining myth. There is an inevitable erosion and replacement of the older narrative by the newer ones. He says,

"The grand narrative has lost its credibility, regardless of what mode of unification it uses, regardless of whether it is a speculative narrative or narrative of emancipation. The decline of narrative can be seen as an effect of the blossoming of technique and technologies since the Second World War, which has shifted emphasis from the ends of action to its means." ${ }^{3}$

It is not the case that the people of modernity are not accepting the myths of the modern era and that is why modernity has lost its credibility and postmodern takes position in place of it. It is also not true to say that the master narratives which reigned in postmodern era have lost their credibility. It is rather that the idea of grand narrative itself has lost its efficacy. In modernity there were innumerable legitimating stories which were conflicting with each other about which we have come across and at the same time we have moved into the age where metanarrative is no longer credible. Thus the period in which everything is 'delegitimized' is called the postmodern era. It demands that any claimant to universality has to be strongly attacked and as such it is said that the demands of postmodern is a 'war on totality'.

Thus when it is said that the grand narrative has lost its efficacy, it means that we are not in search of one system of myth by which human beings can be united into one people or one world. Although the postmodernists are free from any kind of metanarrative, but they are still left with local narratives. Every individual lives in a society and in the context of this society he experiences a world and in order to illumine these experiences, the postmoderns are constantly constructive models of the world. Life is perceived by them as drama or narrative. In order to define personal identity and give purpose and shape to social existence, their concern were centering round the process of fabricating different stories. They are of the opinion that, the models which the modernists use to represent reality is not correct. They termed it as 'illusion' and hence deny its utility. In their view, in our everyday life these models are still serving as 'useful fiction'.

\section{POSTMODERNISM AS THE END OF SCIENCE:}

Lyotard famous comment regarding postmodernism is that it makes the end of science. In understanding knowledge and all aspects of human society, his observation carries important implications. But in modern era his chief concern is the scientific enterprise which has exerted a more significant formative influence. Thus he says that the definition of postmodern condition is the end of the grand narrative. We find that in describing the nature of the world, the primitive peoples use the pre-scientific beliefs, myths and stories and dispelling this modern science arose. In order to legitimate knowledge, the primitive people appeals to narrative, which the modern scientific method undermines. But this attempt is marked by postmodernism as an end. The aim of science is to expel myths from the realm of knowledge, but postmoderns believe that science cannot achieve this goal. In order to legitimize its own enterprise, science, in fact, must inevitably turn to narrative and this is the very endeavour of science to explode.

According to Lyotard, this legitimizing purpose has been served by two major narratives and this has been serving since the 1700s. The idea of the progress towards a goal is embodied by both of these major narratives and the unifying foundations for the different disciplines are provided by each of these narratives. Of these two narratives, the first one is political and the second is philosophical. In modern history, particularly, in the history of knowledge and its institutions both the narratives are of great importance. In order to legitimate science, the political myth appeals to liberty. This myth asserts that right to scientific knowledge is deserved by all people but in attaining this knowledge, priests and tyrants create hindrances. With a view to emancipate itself, humanity rises up in freedom and dignity and this is done through science. It is the bastions of ignorance and oppression assaulting which humanity attain it.

The philosophical narrative is concerned with knowledge. Here the subject is not engaged with knowledge of humanity but knowledge itself. As the scientific enterprise facilitates the growth of knowledge, so

${ }^{3}$ Jean-Francois Lyotard: Postmodern Condition, p-37.

DOI: $10.9790 / 0837-2206125055 \quad$ www.iosrjournals.org
$53 \mid$ Page 
this is asserted by the philosophical narrative as legitimate. This narrative also believes that in gradual evolution of knowledge, there is immense contribution of all the various scientific disciplines.

In addition to these two narratives, there are some other narratives known as 'local' narratives which are being organized by the frame work provided by legitimizing narratives of the 'advance of science'. Around these metanarratives, the stories of new scientific discoveries or the biographies of the heroes of the tradition have been oriented by the modern interpreter. The local narratives echo and confirm the grand narratives of scientific progress and thereby derive their meaning from the way they echo them. These smaller divergent stories are united into a single unified history and this is called the progress of science. But Lyotard is of the opinion that the credibility of the grand narratives of scientific progress has been lost since the Second World War and thereby the age of unified inquiry has come to a close. The result is that science as an organizing and unifying category is losing its credibility. More specifically, he stated that the notion of a cluster of ill-defined and constantly shifting areas of inquiry is replacing the notion of a single scientific enterprise, which is subdivided into well-defined parallel disciplines. There is specific method or procedure of inquiry (language game) for each of these specialties and without any recourse to a universal scientific 'meta-language' it conducts its work. Lyotard says, "New languages are added to the old ones forming suburbs of the old town; "the symbolism of chemistry and the notation of the infinitesimal calculus'. Thirty five years later we can added to the list; machine languages, matrices of game theory, new systems of musical notation, systems of notation for non denotative forms of logic (temporal logics, deontic logic, model logic) the language of the genetic code, graphs of phonological structures."

Now the goal of research has been altered by the splintering of science. In order to legitimate their works, the scholars do not appeal to participation with scientific knowledge. Thus instead of truth, their goal is now 'performativity'. The purpose of financial backers fund is to increase their own power. These are not concerned with the extension of knowledge or for the promotion of the emancipation of humanity. Hence, the question is not concerned with 'truth' but with 'usefulness'. And the question of usefulness means - either 'is it salable'? or 'is it efficient'? The postmodern thinkers admitted that with the loss of scientific metanarrative potential problems appear but this is not painful for them. In the postmodern world multiple incompatible language game flourishes that is why veteran postmodern thinker Lyotard welcomes it. He holds that in heterogeneity of language game consensus creates violence. Invention is fostered in postmodern condition because the birth place of inventions always in dissension not in consensus. He is pleased on the ground that in postmodern world there is no necessity of consensus decision. He admitted that he has discarded the attempts of reconciliation of different language games. Postmodern condition, according to him, heightens our ability to cope with our pluralistic situation and that is why it is beneficial for people. He says, "postmodern knowledge is not simply a tool of the authorities: it refines our sensitivity to differences and re enforces our ability to tolerate the incommensurable. Its principle is not the expert's homology, but the inventor's paralogy."

\section{CONCLUSION}

From the above discussion it is evident that the modern conception of the world as a single and integral is no longer accepted as valid by the postmoderns. Moreover, the moderns' all-encompassing and universally valid explanations are resisted by the postmodern intellectual ethos. They are in favour of differences rather than uniformity. Instead of universal, they respect more the local and particular. It is for this reason they are not displeased with the loss of science as a unifying enterprise. Without being regret they spell the end of the 'world', end of the 'metanarratives' and end of 'science'. But in knowledge situation postmodernism marks the beginning of a revolution.

\section{REFERENCES:}

[1]. Anderson, Perry. The origins of postmodernity. London: Verso, 1998.

[2]. B, David: Postmodern Science and a Postmodern World, in The Reenchantment of Science: Postmodern Proposals, Griffin, David Ray (ed.), Albany: State University of New York Press, 1988.

[3]. Berlin, Isaiah. The Age of enlightenment: The Eightenth Century Philosophers. New York: New American Library, Mentor Books, 1956.

[4]. Gregorios, Paulos, Mar, "On Postmodernism", (Translated by Dr. R.P.Singh) Journal of Indian Council of Philosophical Research, Vol.xiv, No. 3, May-Aug 1997

[5]. . G. Stanley J: A Primer On Postmodernism Cambridge, U.K., 1996.

[6]. Habermas, Jrgen : Lectures on The Philosophical Discourse of Modernity, Translated by- Frederick Lawrence, MIT Press, 1987.

[7]. Hassan, Ihab: The Postmodern Turn: Essays in Postmodern Theory and Culture, Columbus, 1987.

\footnotetext{
${ }^{4}$ Ibid, p-41.

${ }^{5}$ Ibid: p-xxv 
[8]. Lyotard, Jean-Francois: Postmodern Condition: A Report on Knowledge. Trans. Geoff Bennington and Brain Massumi. Manchester University Press, U.K., 1986.

[9]. 9. James B. Miller: The Emerging Postmodern World, in Postmodern Theology: Christian Faith in a Pluralist World, San Francisco: Harper and Row, 1989.

[10]. 10. Jameson, Fredric: Postmodernism, or the Cultural Logic of Late Capitalism, in New Left Review, no. 146, 1984.

[11]. Wittgenstein, L.: Philosophical Investigation, Translated by G. E. M. Anscombe, Basil Blackwel Oxford, 1953. 